Brit. Heart F., 1967, 29, 714.

\title{
Central Venous Pressure and Cardiac Output during Exercise in Coronary Artery Disease
}

\author{
FERENC FOLLATH
}

\author{
From Cardiology Division, Medical Department, University Hospital, Basle, Switzerland
}

There is evidence suggesting that in chronic coronary artery disease the function of the myocardium is impaired even in patients without clinical signs of congestive heart failure. There can be an increase of the pulmonary capillary pressure during exercise (Müller and Rørvik, 1958; Messer et al., 1963). The a-wave of the apex cardiogram is often abnormally high: this is probably the result of raised atrial and left ventricular end-diastolic pressures (Dimond and Benchimol, 1963). The atrial sound occurring during ischæmic pain (Kincaid-Smith and Barlow, 1959) and the abnormality of the $P$ wave in the electrocardiogram (Gross, 1962; Spinelli, 1966) are further arguments. Finally, the patient with coronary artery disease often complains not only of pain but also of dyspnoea at the same time.

Kinetocardiographic investigations in our laboratory have shown that in coronary artery disease the a-wave, referable to atrial action, is often abnormally high (Schweizer, Bertrab, and Reist, 1965). This led to a study of the kinetocardiogram, the central venous pressure, and the cardiac output during exercise in patients with coronary artery disease. The changes in central venous pressure and cardiac output are the subject of this report.

\section{SubJeCtS AND Methods}

Three groups (A, B, C) were examined.

Group $A$ consisted of 8 patients with coronary artery disease, aged between 44 and 59 years. Two patients had been suffering from chronic angina pectoris for more than one year; the others had had a cardiac infarction at least three months before the examination. In no case was heart failure clinically demonstrable. $X$-ray examination revealed normal heart size in each subject. The electrocardiogram showed only signs of the previous infarction and/or ST-T segment changes. The arterial

Received August 20, 1966. pressure was below $150 / 90 \mathrm{~mm}$. Hg. No patient received digitalis or diuretics.

Group $B$ consisted of 8 healthy men, aged between 39 and 59 , with normal hearts, as judged by palpation, auscultation, $x$-ray film, and electrocardiogram (at rest and after exercise).

Group $C$ consisted of 8 healthy men, aged between 20 and 30 years, with normal hearts, as defined above.

The healthy subjects serving as controls were first fully informed about the proposed investigation and the exact nature of their personal contribution. They were then asked if they would like to participate. For the younger Group C (medical students) the information about the procedure itself was detailed, whereas for the older Group B (laymen) only the unpleasant things were mentioned.

The investigations were performed three hours after a normal meal in the supine position without any premedication, and in the following way.

(a) Introduction of a Seldinger catheter through the medial basilic vein into the superior vena cava.

(b) Measurement of the central venous pressure with a manometer; reference point $5 \mathrm{~cm}$. below the manubrium sterni. Recording of two dye-dilution curves with a photoelectric earpiece ${ }^{\star}$ after injection of $20 \mathrm{mg}$. Coomassie blue.

(c) Exercise on the ergometer. After 5 minutes $(50$ watts), a second measurement of the central venous pressure was made and two more dye-dilution curves were recorded. Exercise was discontinued.

(d) After 10 minutes rest, there was a third measurement.

In order to eliminate the errors inseparable from the arbitrarily fixed reference point, only the changes of the central venous pressure and not its absolute values were considered. Percentage changes in cardiac output were calculated from the dye-dilution curves.

* Mark II Electronic Recorder; photoelectric ear attach714 
TABLE

CHANGES IN CARDIAC OUTPUT AND CENTRAL VENOUS PRESSURE WITH EXERCISE

\begin{tabular}{|c|c|c|c|c|c|c|c|c|c|}
\hline \multirow{2}{*}{\multicolumn{2}{|c|}{$\underset{(\text { yr. })}{\text { Subjects and age }}$}} & \multicolumn{2}{|c|}{ Resting } & \multicolumn{3}{|c|}{ During exercise (50 watts) } & \multicolumn{3}{|c|}{10 min. after exercise } \\
\hline & & $\begin{array}{c}\text { Cardiac } \\
\text { output } \\
\text { (\% of initial } \\
\text { value) }\end{array}$ & $\begin{array}{c}\text { Central } \\
\text { venous } \\
\text { pressure } \\
\left(\mathrm{cm} . \mathrm{H}_{2} \mathrm{O}\right)\end{array}$ & $\begin{array}{c}\text { Cardiac } \\
\text { output } \\
\text { (\% of initial } \\
\text { value) }\end{array}$ & $\begin{array}{c}\text { Central } \\
\text { venous } \\
\text { pressure } \\
\left(\mathrm{cm} . \mathrm{H}_{2} \mathrm{O}\right) \\
\end{array}$ & $\begin{array}{c}\text { Change of } \\
\text { pressure } \\
\left(\mathrm{cm} . \mathrm{H}_{2} \mathrm{O}\right)\end{array}$ & $\begin{array}{c}\text { Cardiac } \\
\text { output } \\
\text { (\% of initial } \\
\text { value) }\end{array}$ & $\begin{array}{c}\text { Central } \\
\text { venous } \\
\text { pressure } \\
\left(\mathrm{cm} . \mathrm{H}_{2} \mathrm{O}\right)\end{array}$ & $\begin{array}{c}\text { Change of } \\
\text { pressure } \\
\left(\mathrm{cm} . \mathrm{H}_{2} \mathrm{O}\right)\end{array}$ \\
\hline \multicolumn{10}{|c|}{ GROUP A (coronary artery disease) } \\
\hline $\begin{array}{l}1 \\
2 \\
3 \\
4 \\
5 \\
6 \\
7 \\
8\end{array}$ & $\begin{array}{l}54 \\
44 \\
53 \\
58 \\
59 \\
53 \\
47 \\
47\end{array}$ & $\begin{array}{l}100 \\
\frac{100}{100} \\
100 \\
100 \\
\frac{100}{}\end{array}$ & $\begin{array}{l}4 \cdot 5 \\
5 \cdot 5 \\
1 \cdot 5 \\
1 \cdot 5 \\
3 \cdot 0 \\
3 \cdot 5 \\
3 \cdot 0 \\
3 \cdot 5\end{array}$ & $\begin{array}{l}182 \\
190 \\
150 \\
153 \\
162 \\
\frac{146}{146}\end{array}$ & $\begin{array}{r}9 \cdot 0 \\
9 \cdot 0 \\
4 \cdot 5 \\
8 \cdot 0 \\
8 \cdot 0 \\
16 \cdot 0 \\
12.5 \\
8.5\end{array}$ & $\begin{array}{l}+4.5 \\
+3.5 \\
+3.0 \\
+6.5 \\
+5.0 \\
+12.5 \\
+9.5 \\
+5.0\end{array}$ & $\begin{array}{l}110 \\
\frac{105}{101} \\
127 \\
\frac{124}{95}\end{array}$ & $\begin{array}{l}2 \cdot 5 \\
4 \cdot 5 \\
1 \cdot 0 \\
0 \cdot 5 \\
2 \cdot 0 \\
3 \cdot 5 \\
1 \cdot 0 \\
3 \cdot 0\end{array}$ & $\begin{array}{l}-2.0 \\
-1.0 \\
-0.5 \\
-1.0 \\
-1.0 \\
0 \\
-2.0 \\
-0.5\end{array}$ \\
\hline \multicolumn{10}{|c|}{ GROUP B (normal subjects, age 39-59 years) } \\
\hline $\begin{array}{l}1 \\
2 \\
3 \\
4 \\
5 \\
6 \\
7 \\
8\end{array}$ & $\begin{array}{l}52 \\
39 \\
59 \\
45 \\
46 \\
42 \\
43 \\
48 \\
\end{array}$ & $\begin{array}{l}\frac{100}{100} \\
100 \\
100 \\
100 \\
\frac{100}{100}\end{array}$ & $\begin{array}{l}5 \cdot 0 \\
7 \cdot 5 \\
1.0 \\
7 \cdot 5 \\
4.5 \\
5 \cdot 0 \\
3.0 \\
3.5\end{array}$ & $\begin{array}{l}\frac{153}{138} \\
153 \\
178 \\
178 \\
\frac{188}{188}\end{array}$ & $\begin{array}{r}4.5 \\
9.5 \\
1.0 \\
10.0 \\
7.2 \\
7.5 \\
3.0 \\
6.5\end{array}$ & $\begin{array}{c}-1 \cdot 0 \\
+2.0 \\
0 \\
+2.5 \\
+2.7 \\
+2.5 \\
0 \\
+3.0\end{array}$ & $\begin{array}{l}\frac{97}{104} \\
117 \\
123 \\
\frac{119}{113}\end{array}$ & $\begin{array}{l}4 \cdot 5 \\
6 \cdot 0 \\
0 \cdot 5 \\
6 \cdot 5 \\
3 \cdot 0 \\
3 \cdot 5 \\
4 \cdot 0 \\
2 \cdot 0\end{array}$ & $\begin{array}{l}-0.5 \\
-1.5 \\
-0.5 \\
-1.0 \\
-1.5 \\
-1.5 \\
+1.0 \\
-1.5\end{array}$ \\
\hline \multicolumn{10}{|c|}{ GROUP C (normal subjects, age 20-30 years) } \\
\hline $\begin{array}{l}1 \\
2 \\
3 \\
4 \\
5 \\
6 \\
7 \\
8\end{array}$ & $\begin{array}{l}26 \\
25 \\
23 \\
25 \\
29 \\
24 \\
26 \\
30\end{array}$ & $\begin{array}{l}100 \\
100 \\
100 \\
100 \\
\frac{100}{-} \\
-\end{array}$ & $\begin{array}{r}5 \cdot 0 \\
8 \cdot 5 \\
6 \cdot 0 \\
10 \cdot 5 \\
7 \cdot 5 \\
4 \cdot 0 \\
5 \cdot 5 \\
4 \cdot 0\end{array}$ & $\begin{array}{l}178 \\
177 \\
164 \\
144 \\
\overline{154} \\
=\end{array}$ & $\begin{array}{r}7 \cdot 0 \\
10 \cdot 5 \\
7 \cdot 0 \\
13 \cdot 0 \\
7 \cdot 0 \\
5 \cdot 0 \\
6 \cdot 5 \\
6 \cdot 0\end{array}$ & $\begin{array}{l}+2.0 \\
+2.0 \\
+1.0 \\
+2.5 \\
-0.5 \\
+1.0 \\
+1.0 \\
+2.0\end{array}$ & $\begin{array}{r}113 \\
115 \\
131 \\
97 \\
\frac{107}{-} \\
-\end{array}$ & $\begin{array}{l}4 \cdot 0 \\
8 \cdot 5 \\
4 \cdot 5 \\
8 \cdot 5 \\
6 \cdot 6 \\
3 \cdot 5 \\
4 \cdot 5 \\
4 \cdot 5\end{array}$ & $\begin{array}{l}-1.0 \\
0 \\
-1.5 \\
-2.0 \\
-1.0 \\
-0.5 \\
-1.0 \\
+0.5\end{array}$ \\
\hline
\end{tabular}

\section{RESULTS}

The results are given in the Table and illustrated in Fig. 1-3.

Central Venous Pressure. In subjects with a normal heart (groups $B$ and $C$ ), only a small increase in central venous pressure was noted during exercise, averaging $1.46 \mathrm{~cm} . \mathrm{H}_{2} \mathrm{O}$ (group $\mathrm{B}$ ) and $1.37 \mathrm{~cm} . \mathrm{H}_{2} \mathrm{O}$ (group $\mathrm{C}$ ). In patients with coronary artery disease, however, there was a rise in pressure, the mean value being $6 \cdot 18 \mathrm{~cm} . \mathrm{H}_{2} \mathrm{O}$. The difference is significant ( $\mathrm{p}<0.01$ by the $t$ test).

Cardiac Output. During exercise, the cardiac output rose in all three groups to an average of 63 per cent (group A), 64 per cent (group B), and 62 per cent (group C). No difference could be established between patients with coronary artery disease and normal subjects.

\section{Discussion}

It has been shown that non-calibrated earpiece dye-dilution curves are appropriate for determining relative changes in cardiac output. No differences were noted on comparison with measurements obtained with the arterial cuvette (Gabe, Tuckman, and Shillingford, 1962). The dye-dilution curves recorded in this experiment were satisfactory in all respects (Fig. 3).

In all groups examined, there was a comparable increase in cardiac output during exercise in patients with coronary artery disease and in healthy subjects. This agrees with the findings of several investigators, who observed a normal response of cardiac output to exercise in patients who had recovered from cardiac infarction without residual heart failure (Chapman and Fraser, 1954; Malmcrona, Cramér, and Varnauskas, 1963). In patients with coronary artery disease and clinical signs of myocardial insufficiency, however, this normal response is lacking (Müller and Rørvik, 1958; Thomas and Shillingford, 1965).

In the normal subjects of both age-groups, the venous pressure changed very little during exercise. Observations of others (Szekely, 1941; Hickam and Cargill, 1948) and experimental data (Guyton, 1963) also indicate only insignificant variations of venous pressure during exercise. Surprisingly enough, the central venous pressure rose in every patient with coronary artery disease, though no enlargement of the heart or clinical signs of cardiac insufficiency could be found. Patients with angina on effort and those with cardiac infarction behaved similarly. To 


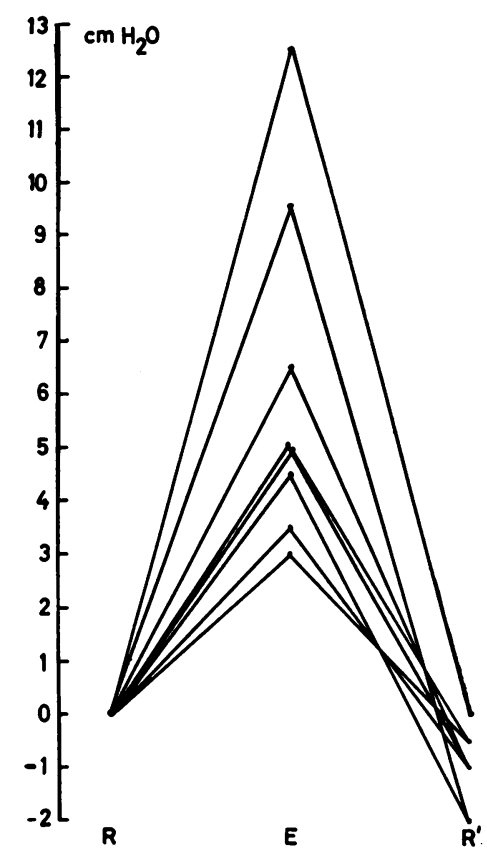

GROUPA

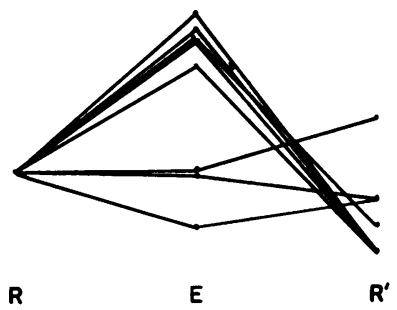

GROUP B

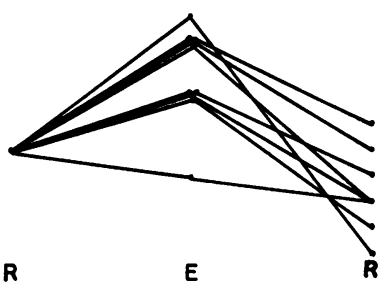

GROUP C

FIG. 1.-Effect of exercise on central venous pressure. There is a distinct rise in patients with coronary artery disease, while the variations in healthy subjects are less pronounced. The difference is significant $(p<0.01) . \quad R=$ rest, $E=$ exercise, $R^{\prime}=10 \mathrm{~min}$. after the end of exercise.

$\left.\begin{array}{l}220 \\ 210 \\ 200 \\ 190 \\ 180 \\ 170 \\ 160 \\ 150 \\ 140 \\ 130 \\ 120 \\ 110 \\ 100 \\ 50 \\ 80\end{array}\right\}$

$\mathrm{CO} \%$
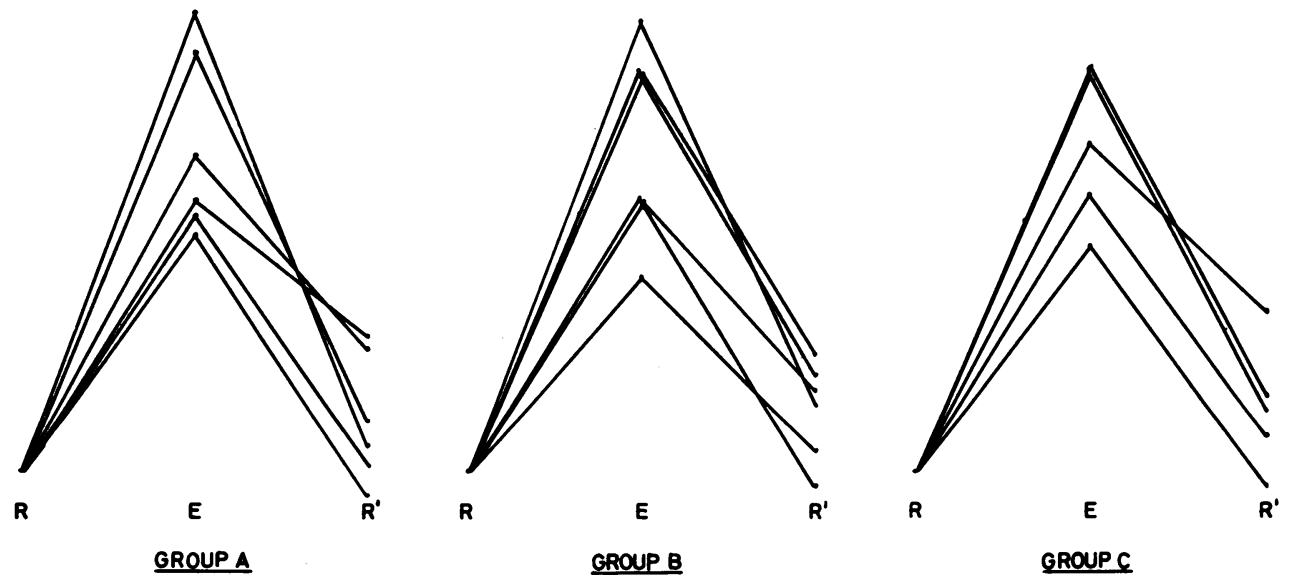

Fig. 2.-Relative changes in cardiac output during exercise. There is no significant difference between patients with coronary artery disease (Group A) and normal subjects (Groups $B$ and $C$ ). $R=$ rest, $E=$ exercise, $R^{\prime}=10 \mathrm{~min}$. after the end of exercise. 


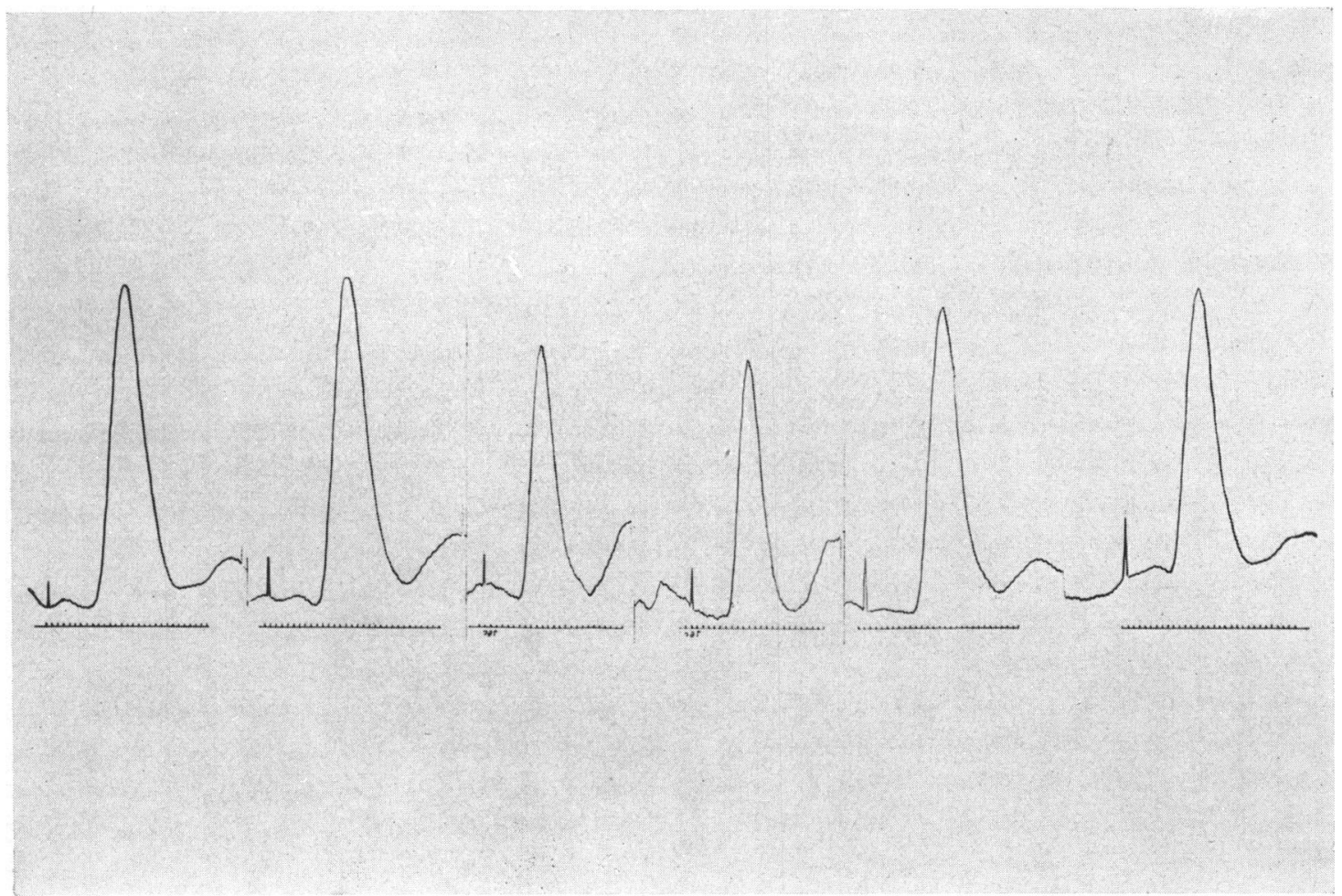

FIG. 3.-Dye-dilution curves during rest (left), exercise (middle), and $10 \mathrm{~min}$. after the end of exercise. Injection of Coomassie blue into the superior vena cava.

our knowledge, no comparable measurements of central venous pressure are on record. Müller and Rørvik (1958) reported an increase of pulmonary capillary pressure during exercise in patients suffering from coronary artery disease, but their results have not been generally confirmed (Messer et al., 1963). Providing the A-V valve function is normal, a rise in right or left atrial pressure must be due to an abnormal end-diastolic ventricular pressure, which is regularly found in congestive heart failure. The increase in venous pressure during exercise may therefore be a sign of latent myocardial insufficiency. In this case, according to Starling's law, the normal cardiac output could only be attained at the cost of an increased filling load.

The discrepancy between the normal increase in cardiac output and the rise in central venous pressure calls, however, for discussion of another pathogenic mechanism: an increase in diastolic filling resistance due to reduced distensibility of the myocardium. This would not necessarily impair forward flow, at least not within the range of work load examined. This assumption is favoured by the fact that the cardiac output can increase without any increase in stroke volume (Chapman and Fraser, 1954; Malmcrona et al., 1963).

\section{SUMMARY}

Changes of cardiac output and central venous pressure during exercise were measured in healthy volunteers and in patients suffering from coronary artery disease without clinical signs of heart failure. An abnormal rise of the central venous pressure in coronary artery disease was found, while the cardiac output increased to comparable levels in both groups. Significance and pathogenic mechanism are discussed.

\section{REFERENCES}

Chapman, C. B., and Fraser, R. S. (1954). Studies on the effect of exercise on cardiovascular function. III. Cardiovascular response to exercise in patients with healed myocardial infarction. Circulation, 9, 347.

Dimond, E. G., and Benchimol, A. (1963). Correlation of intracardiac pressure and præcordial movement in ischæmic heart disease. Brit. Heart f., 25, 389.

Gabe, I. T., Tuckman, J., and Shillingford, J. P. (1962). Determination of relative changes in cardiac output from noncalibrated earpiece dye-dilution curves. Circulat. Res., 11, 405. 
Gross, D. (1962). The clinical significance of $P$ waves with delayed ascent. Amer. Heart F., 63, 497.

Guyton, A. C. (1963). Circulatory Physiology. Cardiac Output and its Regulation. Saunders, Philadelphia.

Hickam, J. B., and Cargill, W. H. (1948). Effect of exercise on cardiac output and pulmonary arterial pressure in normal persons and in patients with cardiovascular disease and pulmonary emphysema. $\mathcal{F}$. clin. Invest., 27, 10.

Kincaid-Smith, P., and Barlow, J. (1959). The atrial sound in hypertension and ischæmic heart disease; with reference to its timing and mode of production. Brit. Heart f., 21, 479.

Malmcrona, R., Cramér, G., and Varnauskas, E. (1963). Hæmodynamic data during rest and exercise of patients who have or have not been able to retain their occupation after myocardial infarction. Acta med. scand., 174, 557.
Messer, J. V., Levine, H. J., Wagman, R. J., and Gorlin, R. (1963). Effect of exercise on cardiac performance in human subjects with coronary artery disease. Circulation, 28, 404.

Müller, O., and Rørvik, K. (1958). Hæmodynamic consequences of coronary heart disease; with observations during anginal pain and on the effect of nitroglycerine. Brit. Heart f., 20, 302.

Schweizer, W., Bertrab, R. V., and Reist, Ph. (1965). Kinetocardiography in coronary artery disease. Brit. Heart F., 27, 263.

Spinelli, F. (1966). Ueber die Bedeutung der P mitrale bei arterieller Hypertension und bei Myocardinfarkt. Z. Kreisl.-Forsch., 55, 1007.

Szekely, P. (1941). Venous pressure responses to exercise. Amer. Heart f., 22, 360.

Thomas, M., and Shillingford, J. (1965). The circulatory response to a standard postural change in ischæmic heart disease. Brit. Heart F., 27, 17. 